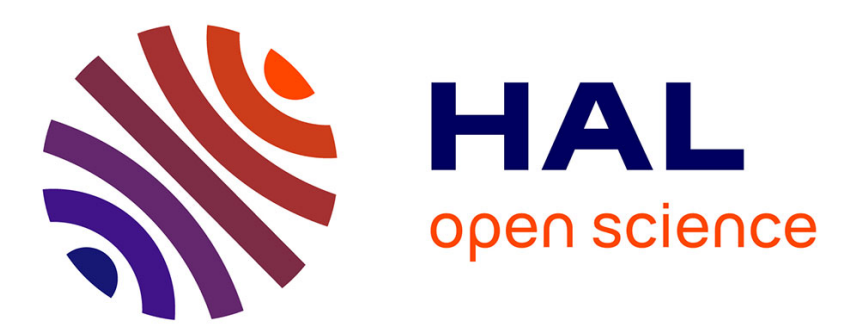

\title{
Preface to the selected papers on spatially explicit landscape modelling: current practices and challenges
}

Cédric Gaucherel, Thomas Houet

\section{To cite this version:}

Cédric Gaucherel, Thomas Houet. Preface to the selected papers on spatially explicit landscape modelling: current practices and challenges. Ecological Modelling, 2009, 220 (24), pp.3477-3480. 10.1016/j.ecolmodel.2009.06.025 . hal-00424087

\section{HAL Id: hal-00424087 \\ https://hal.science/hal-00424087}

Submitted on 8 Sep 2015

HAL is a multi-disciplinary open access archive for the deposit and dissemination of scientific research documents, whether they are published or not. The documents may come from teaching and research institutions in France or abroad, or from public or private research centers.
L'archive ouverte pluridisciplinaire HAL, est destinée au dépôt et à la diffusion de documents scientifiques de niveau recherche, publiés ou non, émanant des établissements d'enseignement et de recherche français ou étrangers, des laboratoires publics ou privés. 


\title{
Preface to the selected papers on spatially explicit landscape modelling: Current practices and challenges
}

\author{
C. Gaucherel ${ }^{\mathrm{a}, *}$, T. Houet $^{\mathrm{b}, 1}$ \\ a INRA UMR AMAP - Bd de la Lironde TA A-51/PS2, 34398 Montpellier Cedex 5, France \\ b GEODE UMR 5602 CNRS - Université Toulouse 2, 5 allée Antonio Machado, 31058 Toulouse Cedex 9, France
}

\section{A R T I C L E I N F O}

\section{Article history:}

Available online 29 July 2009

\section{Keywords:}

Landscape

Models

Review

\begin{abstract}
A B S T R A C $T$
In the past 30 years, the notion of landscape has emerged in ecology as a result of both theoretical strategies and practical aspects of land use. This has generated a variety of computerized models addressing both objectives and techniques. Scientists model landscapes for at least two reasons: to better understand the landscape dynamics themselves (called intrinsic needs) and to offer a realistic frame to support other ecological processes (extrinsic needs). This special issue concerns both needs and illustrates the way socioeconomic and/or ecological mechanisms of various landscapes have been understood through modelling approaches. It outlines the links between landscape and model concepts, focusing on one hand on several landscape types (agricultural, forested and aquatic) and on the other hand on several landscape model characteristics (explicit or neutral, dynamic or static, patchy or continuous and multi- or monoscale). The patterns and processes of each landscape model presented in this issue, in particular, should be analysed in order to highlight the way they are contributing to the landscape ecology discipline. We finally argue that the discipline can now offer a theoretical dimension to landscape dynamics, aiming at understanding the possible mechanism unity underlying this complex object.
\end{abstract}

(C) 2009 Elsevier B.V. All rights reserved.

\section{Context}

The concept of landscape has become increasingly widespread in ecology. Separated from, yet complementary to, the ecosystem, this notion encompasses elements of various natures and several scales of perception and analysis (Turner and Gardner, 1991; Forman, 1995; Dungan et al., 2002). The concept emerged from a combination of land planning issues, theoretical approaches and technological progress. Lying between local strategies that focus on management of agricultural and forest areas and urban and suburban zones, and those for whole regions, landscape is often perceived as an intermediate level of organisation, prone to be managed (Shoute et al., 1994; Twery, 2004; Mérot et al., 2006). In parallel, recent progress in computer science, data and information representation and algorithms, have enabled the development of modelling strategies for these objectives (Coquillard and Hill, 1997; Blasco and Weill, 1999). The central paradigm of landscape ecology is that the spatial structures of a landscape have an effect

\footnotetext{
* Corresponding author at: GEODE UMR 5602 CNRS - Université Toulouse 2, 5 allée Antonio Machado, 31058 Toulouse Cedex 9, France. Tel.: +33 (0) 4676156 08; fax: +33 (0) 467615668 .

E-mail addresses: cedric.gaucherel@cirad.fr (C. Gaucherel), thomas.houet@univ-tlse2.fr (T. Houet).

${ }^{1}$ Tel.: +33 (0) 5615036 28; fax: +33 (0) 467614275 .
}

on the movements of individuals and the flow of matter it shelters (Forman, 1995; Burel and Baudry, 2003). Certain properties of the landscape such as heterogeneity, connectivity or fragmentation strongly influence the exchange and flow of organisms, matter and energy between the different components (Ricklefs and Miller, 2000). Moreover, this branch of ecology insists on the importance of scales and integration of processes, suggesting a holistic approach to landscape (Turner et al., 1993; Dungan et al., 2002). Other fields of investigation, sometimes less theoretical, have benefited from landscape analysis. Today, forest management is able to consider a forest landscape (sometimes restricted to a single stand) in order to study its evolution and assist in management (Twery, 2004). Physical geography and remote sensing studies are also a great source of inspiration when considering landscape models (Lambin et al., 2000).

Landscape studies are not concerned with energy or mass balances (e.g. element cycles, trophic networks), with specific ecological processes (e.g. tree growth, sedimentation of a water course) or the closure (i.e. no exchange outside the system) of ecosystems. Landscapes are gathering elements of very different natures (e.g. crop fields, rivers, roads, buildings, ...) that are continuously interacting at various scales (Burel and Baudry, 2003). Landscape modelling may help to formulate, test and validate a hypothesis, often in spatial and temporal dimensions that are impossible to create and validate with in situ experiments. Other models (rarely the same as the preceding ones) can help to manage a system, to 
visualise it and make forecasts by implementing different scenarios. Several reviews of environmental models can be found in recent literature (Jorgensen and Bendoricchio, 2001; Müller and Steinhardt, 2003), together with numerical simulations of landscape models where the notion of landscape is more present (Baker, 1989; Sklar and Costanza, 1991; Mladenoff and Baker, 1999). Although these syntheses insist on specific features of current models such as spatial, temporal, and/or integrated descriptions, but they are not at all exhaustive in terms of landscape properties or model characteristics. We argue that they do not as yet emphasise any landscape properties or model characteristics in order to offer a coherent conceptual framework for landscape dynamics studies.

There are several ways of modelling a landscape: by interpolation, using cartography, with a process-explicit model or a neutral model. The first two types generally simulate spatial distribution of variables using statistical, multi-scale, geometrical and/or topological properties (through GIS) of their spatial patterns (Mackey, 2000; Kyriakidis, 2003). However, they rarely highlight landscape dynamics. Therefore these models are not known as «landscape models" and concern "spatial models on the scale of landscape», using landscape only as fixed support. Landscape models, in our sense, are mainly those highlighting the changes in land use: vegetation cover (forestry, agronomy, etc.), urbanisation (geography) or natural forms (geomorphology, soil studies, etc.). This temporal aspect, necessary in ecology and in the study of the landscape object, leads us to give details concerning the two last types of models. Process-explicit models reproduce a landscape by implementing one or several specific processes (Gaucherel et al., 2006b). They are complementary to neutral models which simulate landscapes with the patterns and statistical properties expected in the absence of studied processes (Gardner and O'Neill, 1991; With and King, 1997). Unlike explicit landscape models that would simulate dynamic functions and relations of landscape elements, these models do not try to reproduce the spatial patterns of any given real landscape. Neutral models deal more particularly with one of the characteristics of composition and configuration of real landscapes (With and King, 1997; Gaucherel et al., 2006a).

The authors for this issue were selected from a panel of authors that participated to the international symposium on "Spatial landscape modelling: from dynamic approaches to functional evaluations" which occurred in Toulouse (France), June 2008 (http://w3.geode.univ-tlse2.fr/rtp-modelisation/eng_index.htm). Its objective was to give an overview of current practices in the field of spatial landscape modelling, confronting developer and user approaches in order to point out future research challenges on spatial and temporal landscape modelling. This special issue aims at presenting a synthesis that characterizes landscape modelling approaches through the lens of four dimensions discussed below, summarizing main conclusions of this symposium. The resulting papers cover a wide range of theoretical and practical considerations, and together illustrate the diversity of existing spatial landscape models. Saltré et al. (2009) present an original algorithm to reconstruct spatial and temporal species dispersion in Europe over thousands of years based on palaeo-environmental data. Such an approach would be useful for palaeo-ecologists and landscape ecologists to better understand how history matters (Gillson, 2009) either as geography (altitude, latitude, ...). Gomez-Gutierrez et al. (2009) have respectively tested and developed models that also deal with DEM (Digital Elevation Model) data. Conversely to Saltré et al. (2009), they focus on fine scales and prediction of areas with environmental stakes. Indeed, the first paper aims to automatically detect area potentially concerned by gully erosion in Spain. Le Ber et al. (2009) and Chaput-Bardy et al. (2009) illustrate how models can contribute to explain how landscapes characteristics and/or dynamics influence gene flow and/or biodiversity. While dealing with very different landscapes (agricultural and aquatic), these papers illustrate that models could be efficient tools to evaluate how human activities/landscape configuration influence fluxes of matters and organisms. The last paper (Degenne et al., 2009) demonstrates that spatial landscape modelling, whatever the environmental issue, needs to refer to theoretical research to improve and facilitate development of such models. Finally, the papers in this special issue present an overview of the insights available to landscape ecologists, landscape modellers and all scientists working on modelling landscape dynamics.

\section{Discussion}

A rapid synthesis of modelled landscapes emerging from the review of the literature and on the models of this issue indicates the presence of dimensions (or polarisations) in relation to the design choice. The modelled landscapes have (a) a varying degree of landscape discontinuity (raster-vector); (b) various spatial and temporal dimensions (involving different scales), (c) operations dealing with diverse landscape elements; and (d) distinct degrees of specificity and finality.

(a) Firstly, we observe a dichotomy between those landscapes perceived as homogeneous patches and those with spatial gradients (continuous fields) which cannot be classified into a particular model type. If the component of a studied landscape is continuous, such as topographical elevation, latitudinal degree or bathymetric areas, physico-chemical equations can generally be used to remove segmentation bias and geometrical modifications not easy to avoid in landscapes. Rural landscapes are often discontinuous, but can also host continuous types of processes (pollens, pesticides, etc.) (Levin et al., 1993; Wu and Levin, 1997; Saltré et al., 2009). We have mentioned some of the works dealing with these discontinuous landscapes made up from uniform patches with distinct, well-defined borders (Forman and Godron, 1981; Kotliar and Wiens, 1990; Wu and Levin, 1994). As seen from the literature, especially with regard to neutral landscape models (Gaucherel et al., 2006a; Le Ber et al., 2009), the continuity or discontinuity of a landscape cannot be modelled in the same way.

(b) Undoubtedly the most interesting aspect of landscape models is to try to reproduce the dynamics they host. But which dynamics? Those of the first two dimensions $[x, y, t]$, that concentrate on the evolutions in the structure of horizontal landscape. These are the prime dimensions in landscape ecology and remote sensing. Are we more interested in vertical dynamics $[z, t]$, involving mainly digital terrain models (Saltré et al., 2009; Gomez-Gutierrez et al., 2009) and plant (or building) growth (Prusinkiewicz et al., 2000; Kang et al., 2008)? Hydrology, soil sciences and plant modelling all provide information for these dynamics, but other, more complex, approaches could be considered, involving simultaneously the dynamics of $2 \mathrm{D}$ landscape structures and growth in vegetation height or land erosion $[x, y, z, t]$. Very few attempts to develop functional landscape models in four dimensions exist.

(c) Beyond the question of landscape dimensions, there are also marked differences in landscape evolutions. We have mentioned Land-Use and Land-Cover Changes (LUCC) models which essentially take into account the attributes of landscape elements (Lambin et al., 2000; Mackey, 2000): they modify the dominant type of element (the attribute of a patch, a group of pixels) called the landscape composition, but do not change the shape or the spatial arrangements of these elements called the landscape configuration. We qualified these latter operations as geometrical operations and noted that they remain relatively rare amongst landscape models (Le Ber et al., 2009). 
Their development and calculation time are costly, but they are now increasingly being implemented in landscape studies (With and King, 1997; Gaucherel et al., 2006a). In particular, landscape models focusing on linear networks such as road networks or hydrographical networks are specifically addressing the question of landscape configuration (Chaput-Bardy et al., 2009).

(d) Close examination of landscape models shows that objectives may vary. What are the objectives of these models? Do we want to check one or several hypotheses, or produce software or business packages? In this context, two model structures that have produced promising results for environmental issues, are in our opinion well adapted to landscape modelling: that of a domainspecific language (Fall and Fall, 2001; Degenne et al., 2009) and that of modelling platform. A domain-specific language uses a kernel of data, knowledge and methods surrounded by models specific to certain applications (less costly to design). This is situated mid-way between a multitude of small, object-specific models that are effective, but costly with, by definition, local results, and a universal, utopian model that could provide solutions to all objectives. This concept is not far away in one sense of other platforms such as SME (Costanza and Voinov, 2004), CAPSIS (De Coligny et al., 2004) or L1/DYPAL (Gaucherel et al., 2006 b), except that it also provides a language to improve modelling ease.

\section{Conclusion}

At present, there is a need for landscape modelling to progress in many ecological disciplines. For example, different components must be integrated into landscape. Today, closer coupling between fine and large scale models, between biophysical and socioeconomic factors is being implemented into landscape dynamics (Palang et al., 2000; Osinski et al., 2003). This coupling is all the more necessary today since the effects of man on the environment are becoming increasingly obvious. An integrative approach could be considered by coupling with other environmental models simulating atmospheric, underground and/or biological components of the landscape. Working in four dimensions and/or using domainspecific languages may be necessary in ecology (Degenne et al., 2009). These are promising strategies since they favour integrating ecological phenomena and provide a holistic view of ecosystems too. Landscape models that take into account their possible geometrical evolution, that are not limited to random change, and that adopt a patchy description in homogeneous landscape units, unlike a raster description, also seem to have a promising future. The small number of modelling approaches using only mechanistic landscape models, specifically describing how to change landscape components, leads us to further research along these lines using recent knowledge on ecological and socio-technical functioning of landscape and on fluxes. Landscape is a concept that can federate different environmental strategies.

\section{Acknowledgments}

This special issue and the symposium have been supported by the French Thematic Interdisciplinary Network on «Landscape and Environment» of the department Human and Social Sciences of CNRS (National Centre for Scientific Research), the Region MidiPyrénées, the University of Toulouse Le Mirail and the GEODE Laboratory (CNRS UMR 5602). We would like to thank all the 30 reviewers that have contributed to this result by their constructive comments.

\section{References}

Baker, W.L., 1989. A review of models of landscape change. Landscape Ecology 2 111-135.

Blasco, F., Weill, A., 1999. Advances in Environmental and Ecological Modelling. Elsevier, Paris, p. 219.

Burel, F., Baudry, J., 2003. Landscape Ecology: Concepts, Methods, and Applications. Science Publishers, Enfield, N.H, p. 362.

Chaput-Bardy, A., Fleurant, C., Lemaire, C., Secondi, J., 2009. Modelling the effect of in-stream and overland dispersal on gene flow in river network. Ecological Modelling 220, 3589-3598.

Coquillard, P., Hill, D.R.C., 1997. Modélisation et simulation d'écosystèmes: des modèles déterministes aux simulations à évènements discrets. Recherche en écologie. Masson, Paris.

Costanza, R., Voinov, A., 2004. Landscape Simulation Modeling. A Spatially Explicit, Dynamic Approach. Springer Verlag New York Inc, p. 330

De Coligny, F., Ancelin, P., Cornu, G., Courbaud, B., Dreyfus, P., Goreaud, F., GourletFleury, S., Meredieu, C., Orazio, C., Saint-André, L., 2004. Capsis: Computer-Aided Projection for Strategies in Silviculture: Open Architecture for a Shared ForestModelling Platform. IUFRO Working Party S5.01-04. A.G., Wust-Sancy, Harrison, British Columbia, Canada, pp. 371-380.

Degenne, P., Lo Seen, D., Parigot, D., Forax, R., Tran, A., 2009. Design of a domain specific language for modelling processes in landscapes. Ecological Modelling 220, 3527-3535.

Dungan, J.L., Perry, J.N., Dale, M.R.T., Legendre, P., Citron-Pousty, S., Fortin, M.J., Jakomulska, A., Miriti, M., Rosenberg, M.S., 2002. A balanced view of scale in spatial statistical analysis. Ecography 25, 626-640.

Fall, A., Fall, J., 2001. A domain-specific language for models of landscape dynamics. Ecological Modelling 141, 1-18.

Forman, R.T.T., 1995. Some general-principles of landscape and regional ecology. Landscape Ecology 10, 133-142.

Forman, R.T.T., Godron, M., 1981. Patches and structural components for a landscape ecology. BioScience 31, 733-740.

Gardner, R.H., O’Neill, R.V., 1991. Patternprocess and predictability: the use of neutral model for landscape analysis. In: Turner, M.G., Gardner, R.H. (Eds.), Quantitative Methods in Landscape Ecology. Ecological Studies. Springer-Verlag, New-York.

Gaucherel, C., Fleury, D., Auclair, A., Dreyfus, P., 2006a. Neutral models for patchy landscapes. Ecological Modelling 197, 159-170.

Gaucherel, C., Giboire, N., Viaud, V., Houet, T., Baudry, J., Burel, F., 2006b. A domain specific language for patchy landscape modelling: the brittany agricultural mosaic as a case study. Ecological Modelling 194, 233-243.

Gillson, L., 2009. Landscape in time and space. Landscape Ecology 24, 149-155.

Gomez-Gutierrez, A., Schnabel, S., Lavado Contador, F.J., 2009. Using and comparing two non parametric methods (CART and MARS) to model the potential distribution of gullies. Ecological Modelling 220, 3630-3637.

Jorgensen, S.E., Bendoricchio, G., 2001. Fundamentals of ecological modeling. In: Science B.V. Developments in Environmental Modelling, no. 21. Elsevier, p. 530.

Kang, M.Z., Cournède, P.H., De Reffye, P., Auclair, D., Hu, B.G., 2008. Mathematics and Computers in Simulation 78 (1), 57-75.

Kotliar, N.B., Wiens, J.A., 1990. Multiple scales of patchiness and patch structure: a hierarchical framework for the study of heterogeneity. Oikos 59, 523-560.

Kyriakidis, P., 2003. Geostatistics for environmental scientists. International Journal of Geographical Information Science 17, 198-200.

Lambin, E.F., Rounsevell, M.D.A., Geist, H.J., 2000. Are agricultural land-use models able to predict changes in land-use intensity? Agriculture Ecosystems and Environment 82, 321-331.

Le Ber, F., Adamczyk, K., Lavigne, C., Mari, J.-F., Angevin, F., Monod, H., Colbach, N., 2009. Modelling neutral agricultural landscapes with tessellation methods-application for gene flow simulation. Ecological Modelling 220, 3536-3545.

Levin, S.A., Powell, T.M., Steele, J.H., 1993. Patch Dynamics. Springer, Berlin, p. 307.

Mackey, B.G., 2000. GIS for ecology: an introduction. International Journal of Geographical Information Science 14, 107-1107.

Mérot, P., Hubert-Moy, L., Gascuel-Odoux, C., Clément, B., Durand, P., Baudry, J., Thenail, C., 2006. A method for improving the management of controversial wetland. Environmental Management 37 (2), 258-270.

Mladenoff, D.J., Baker, W.L., 1999. Spatial Modeling of Forest Landscape Change. Approaches and Applications. Cambridge University Press, Cambridge, UK, p. 352 .

Müller, F., Steinhardt, U., 2003. Landscape modelling and landscape analysis. Ecological Modelling 168, 215-389.

Osinski, E., Kantelhardt, J., Heissenhuber, A., 2003. Economic perspectives of using indicators. Agriculture Ecosystems and Environment 98, 477-482.

Palang, H., Alumae, H., Mander, U., 2000. Holistic aspects in landscape development: a scenario approach. Landscape and Urban Planning 50, 85-94.

Prusinkiewicz, P., Hanan, J., Mech., R., 2000. An L-system-based plant modeling language. In: Nagl, M., Schuerr, A. and Muench, M. (Eds), Applications of graph transformations with industrial relevance. Proceedings of the International workshop AGTIVE'99, Kerkrade, The Netherlands, September 1999. Lecture Notes in Computer Science 1779, Springer, Berlin, pp.395-410.

Saltré, F., Chuine, I., Brewer, S., Gaucherel, C., 2009. A phenomenological model without dispersal kernel to model species migration. Ecological Modelling 220, 3546-3554.

Shoute, J.F.T., Finlke, A.F., Veeneklaas, F.R., Wolfert, H.P., 1994. Scenario Studies For The Rural Environment. Environment and Policy, Kluwer Academic Publisher, p. 743. 
Sklar, F.H., Costanza, R., 1991. The development of dynamic spatial models for landscape ecology: a review and prognosis. In: Turner, M.G., Gardner, R.H. (Eds.), Quantitative Methods in Landscape Ecology. Springer, New York, USA, pp. 239-288.

Ricklefs, R.E., Miller, G.L., 2000. Ecology, fourth ed. W.H. Freeman and Co., New York, p. 822 .

Turner, M.G., Gardner, R.H., 1991. Quantitative Methods in Landscape Ecology. Springer Verlag, New York.

Turner, M.G., Romme, W.H., Gardner, R.H., Oneill, R.V., Kratz, T.K., 1993. A revised concept of landscape equilibrium-disturbance and stability on scaled landscapes. Landscape Ecology 8, 213-227.
Twery, M.J., 2004. Modelling in forest management. In: Wainwright, J., Mulligan, M. (Eds.), Environmental Modelling-Finding Simplicity in Complexity. Wiley, Chichester, UK, pp. 291-301.

With, K.A., King, A.W., 1997. The use and misuse of neutral landscape models in ecology. Oikos 79, 219-229.

Wu, J.G., Levin, S.A., 1994. A spatial patch dynamic modeling approach to pattern and process in an annual grassland. Ecological Monographs 64, 447464.

Wu, J.G., Levin, S.A., 1997. A patch-based spatial modeling approach: conceptual framework and simulation scheme. Ecological Modelling 101, 325-346. 